\title{
Policy priority objectives: comparative assessment in four European cities
}

\author{
Andrea Alonso \\ TRANSyT Transport Research Centre- Universidad Politécnica de Madrid \\ Andrés Monzón \\ Civil Engineer Department- Universidad Politécnica de Madrid
}

\begin{abstract}
Sustainability must be an urban issue. Cities should be managed so as to minimize their impacts on environment, but providing an appropriate framework for economic and social development. However, European cities are facing some trends that threaten sustainable development. The aim of the EC research project INSIGHT-7FP (2013/16) is to develop appropriate management tools that can help to achieve sustainability in the context of European cities. In the project, a set of policy objectives have been designed for the management of urban areas, in order to face the main threats existing over cities. The paper presents a methodology based on indicators for analysing the progress towards these ten policy objectives in the four EU cities participating in the project: London (12.3 mill. inhab.), Madrid (6.4 mill. inhab.), Barcelona (5.4 mill. inhab.) and Rotterdam (1.4 mill. inhab.). All the indicators used in the analysis have been validated by ten policy makers of European cities. These policy makers participated on the stakeholders consultation carried out in the project, where the importance of the policy objectives proposed was also assessed. The paper concludes determining the policy priority objectives in each city, in order to contain the main threats existing over them: London should especially address the threats of social exclusion and transport inefficiency; Madrid the threats of economic decline and urban sprawl; Barcelona the economic decline and Rotterdam the contribution to climate change and the urban sprawl. Finally, the role played by the land use and transport system in these policy objectives is analysed. To this end, the assessment allows for the comparability of the results in a horizontal manner, in the basis of common indicators. Nearly half of these indicators are related to the land use and transport system of the cities.
\end{abstract}




\section{GLOSSARY OF TERMS}

GGE: Greenhouse Gases Emissions ( $\mathrm{CO}_{2}$ equivalent)

Metropolitan Area: geographical area where there is a high degree of interaction between its urban centres in terms of trips, relationships or economic activity

Central City: core city in the metropolitan area

Metropolitan Ring: Metropolitan area excluding Central City

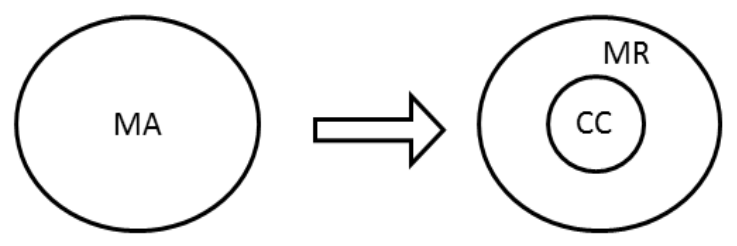

Fig. 1. Scheme of the components of a city. MA includes CC and MR

\section{INTRODUCTION AND BACKGROUND}

Sustainability must be an urban issue (Newman and Kenworthy, 1999). Cities should be managed so as to minimize their impacts on environment, but providing an appropriate framework for economic and social development (United Nations, 1972). In Europe, over $60 \%$ of the population lives in cities, where a bit less than $85 \%$ of the EU's GDP is generated (European Commission, 2007). Urban areas play a key role in the development of European territories. However, European cities are nowadays facing some trends that threaten sustainable development (European Union, 2011). "The aim of the research project INSIGHT-7 FP (2015) is to develop appropriate management tools that can help to achieve sustainability in the context of European cities". In the project, ten sustainability objectives have been designed for the management of urban areas, in order to face the main threats over cities (Romanillos et al., 2014). This paper presents a methodology based on indicators for analysing the progress towards the objectives designed. Indicators are considered to be appropriated tools to analyse the many overlapping areas of sustainability (Newman and Kenworthy, 1999), and many authors have already applied them to cities for this very purpose (Tanguay, 2010; Haghshenas and Vaziri., 2012; Alonso et al., 2015). All the indicators used in the analysis have been validated by ten policy makers of European cities. These policy makers participated on the stakeholders consultation carried out in the project (García et al., 2014). The methodology developed is applied to the cities of London, Madrid, Barcelona and Rotterdam, which are the four case studies of the project. The progress towards the objectives in each case is comparatively analysed. Finally, the role played by urban transport management in the progress or deviation from the objectives is showed.

The paper aims to develop a methodology to analyse if we are achieving the objectives in city management, specifically the sustainability objectives proposed. This will allow 
prioritizing the objectives and the policies to be implemented, including transport management policies. The paper is structured in five sections. Section 2 details framework and methods used for the analysis. Section 3 presents the results. Section 5 then concludes, summarising the key findings that can be useful for future policy and research.

\section{FRAMEWORK AND METHODOLOGY}

This section explains the theoretical framework developed in INSIGHT, which has set the basis of the analysis, and introduces the case study application. Finally, the section details the methods used to get the results.

\subsection{Theoretical framework for urban planning in European cities- setting the objectives} The first step of INSIGHT project was to study the main trends that threaten sustainability in European cities, in order to design appropriate objectives and policies for city management. For this, we recurred to the main reference document on urban problems at European level, which comes from the initiative Cities of Tomorrow (European Union, 2011). Considering sustainable development as a concept divided into three dimensions: society, environment and economy (OECD, 2002; Tanguay et al., 2010; Haghshenas and Vaziri, 2012), the main trends existing in European cities and threatening each dimension are described below:

Society: the weight of working-age population is decreasing due to the low birth rate, the increase in life expectancy and the migration of active population due to the lack of job opportunities. In addition, the socio-spatial segregation is growing, associated to socioeconomic inequalities. Urban transport systems are related to this trend, since they affect the livability of cities and provide accessibility (a concept linked to equity).

Environment: the endless consumption of natural resources during urban growth and sprawl continues to pose a threat to the environment. This negative impact of urban development must be addressed to contain the resulting environmental damage.

Economy: a lot of problems associated with economic sustainability started appearing with the Eurozone crisis. The recent recession has been putting pressure over economic development and competitiveness.

Finally, urban sprawl witnessed by Europe in the latest decades has adversely impacted society, environment and economic efficiency (European Environment Agency, 2006). Therefore, sprawling can be considered as a horizontal threat to sustainability, based on the aforementioned dimensions. Despite the classification, the threats described under each dimension are interrelated. 


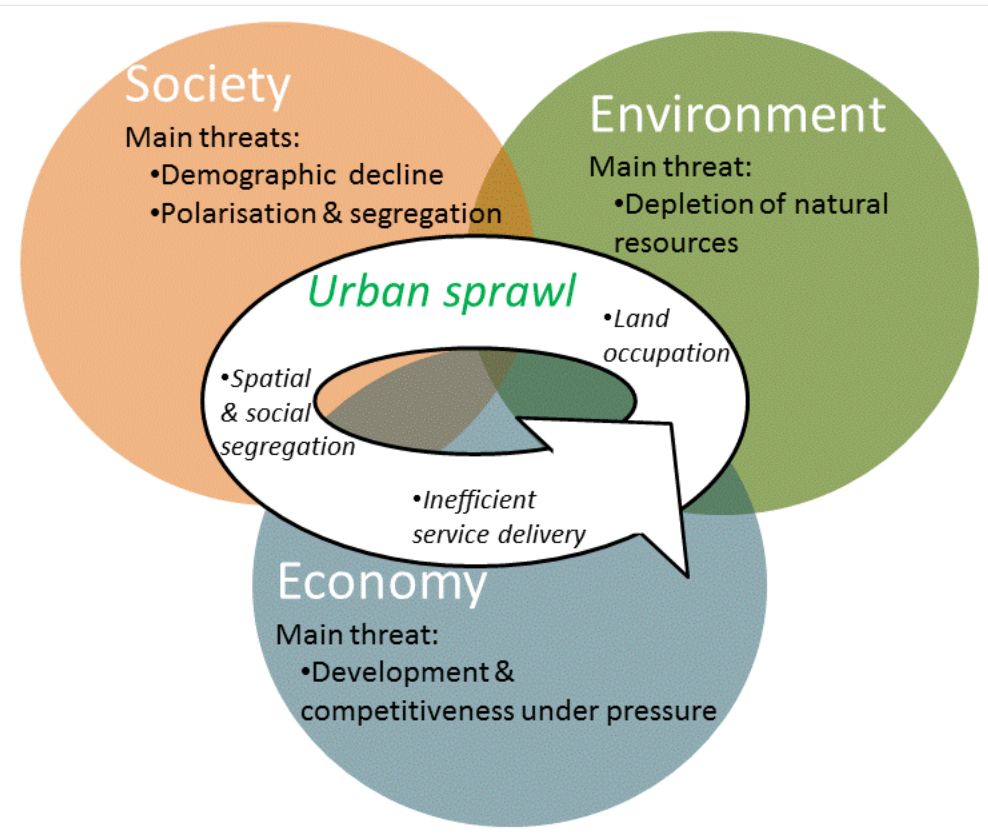

Fig. 2 - Main trends existing in European cities and threatening sustainability Romanillos et al. (2014)

At the initial stage of the project, we designed ten sustainability objectives in order to face these threats, and we proposed several indicators for measuring the achievement of each objective (Romanillos et al., 2014). All these outcomes were evaluated in the stakeholder's consultation that was held in the project (García et al., 2014). In the consultation process, ten policy makers of European cities had to select the most important objectives from the list. The stakeholders also assessed the indicators proposed. All the indicators used in this analysis were considered to be relevant for their correspondent objectives by the majority of the stakeholders consulted. Table 1 summarises the sustainability objectives designed in the project and the main results of the stakeholder's consultation process. The detailed list of validated and available indicators in the four cities is showed later on in Table 4, with the correspondent values in each city. All this theoretical background has served to stablish the policy priorities in each city and the role played by the transport system. 


\begin{tabular}{|c|c|c|}
\hline $\begin{array}{l}\text { Sustainability objective } \\
\begin{array}{l}\text { Designed after a literature review } \\
\text { about the main problems existing in } \\
\text { cities }\end{array}\end{array}$ & $\begin{array}{l}\text { Importance according to policy } \\
\text { makers } \\
\text { Asked to select } 2-3 \text { objectives }\end{array}$ & $\begin{array}{l}\text { No. validated indicators } \\
\text { Considered relevant for the } \\
\text { objective by the majority of } \\
\text { stakeholders } \\
\text { (at least by } 5 \text { of } 10 \text { stakeholders) }\end{array}$ \\
\hline Economic growth & $\begin{array}{l}\text { Essential } \\
\text { (selected by } 6 \text { of } 10 \text { stakeholders) }\end{array}$ & 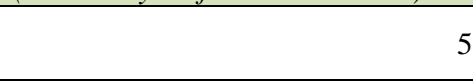 \\
\hline Economic efficiency & $\begin{array}{l}\text { Little importance } \\
\text { (selected by } 2 \text { of } 10 \text { stakeholders) }\end{array}$ & 3 \\
\hline $\begin{array}{l}\text { Liveable streets and } \\
\text { neighbourhoods }\end{array}$ & $\begin{array}{l}\text { Very important } \\
\text { (selected by } 5 \text { of } 10 \text { stakeholders) }\end{array}$ & 5 \\
\hline Equal, safe and secure society & $\begin{array}{l}\text { Neutral } \\
\text { (selected by } 3 \text { of } 10 \text { stakeholders) }\end{array}$ & 11 \\
\hline Stop demographic decline & $\begin{array}{l}\text { Unimportant } \\
\text { (selected by } 0 \text { of } 10 \text { stakeholders) }\end{array}$ & 4 \\
\hline $\begin{array}{l}\text { Reduce contribution to climate } \\
\text { change }\end{array}$ & $\begin{array}{l}\text { Important } \\
\text { (selected by } 4 \text { of } 10 \text { stakeholders) }\end{array}$ & 3 \\
\hline Reduce pollution & $\begin{array}{l}\text { Very important } \\
\text { (selected by } 5 \text { of } 10 \text { stakeholders) }\end{array}$ & 6 \\
\hline Reduce urban sprawl & $\begin{array}{l}\text { Important } \\
\text { (selected by } 4 \text { of } 10 \text { stakeholders) }\end{array}$ & 3 \\
\hline
\end{tabular}

Table 1 - Sustainability objectives for EU cities. Summary of the policy makers' assessment

Compiled by authors from Romanillos et al. (2014) and García et al. (2014)

Table 1 shows the importance attached to the objectives by policy makers. The main objective for most of them resulted to be the economic growth. This concern was especially influenced by the economic crisis, which began to hit the global economy in the summer of 2007 (Directorate- General for Economic and Financial Affairs of the European Commission, 2009). It is noted that more than two thirds of the European Union's workforce live in cities (European Union, 2011). Many of these cities are now exhibiting a dual personality of economic strength co-existing with weak demand and unemployment (Campbell et al. 2013). Unemployment reduction is a top priority across European cities, since the beginning of the European recession which has caused a large drop in economic activity in the EU, with millions of jobs lost (European Commission, 2012).

Environmental objectives were also considered of high importance. The concern about damages of urban development to natural resources is not new. Environmental sustainability objectives such as stop contribution to climate change or reduce pollution are probably the most classical policy objectives in this comparative (European Union, 2011). In fact, most stakeholders declared their commitment with these problems.

The objective of economic efficiency as well as other social objectives such as equity and to stop demographic decline were of lower priority.

\subsection{Case studies}

The four European cities involved in INSIGHT project are from three different countries, presenting heterogeneous characteristics and sizes (Fig. 3 and Table 2). There are two capital cities, London (England) and Madrid (Spain), both accounting for a significant percentage 
of their countries (19 and $14 \%$ respectively) (EUROSTAT- General Statistics). However, their sizes are very different; the population of London (12 million inhab.) nearly doubles the population of Madrid (6 million inhab.). The city of Barcelona (Spain) is very similar to Madrid in size and relevance for the country. Rotterdam with 1.4 million inhabitants is the smallest in this comparative, accounting for a $8 \%$ of the population in Netherlands. Geographically, we have two cities from Southern Europe and two from Northern Europe. This will make differences in the results since the recent economic crisis has especially impacted Southern cities (European Union, 2011).

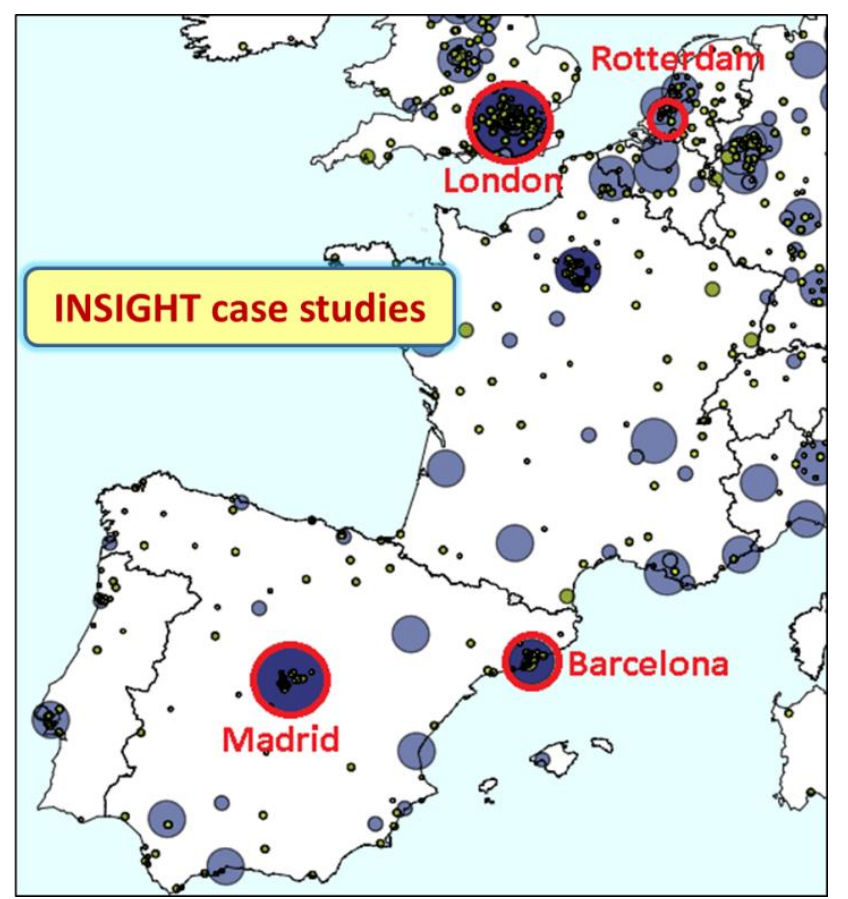

Fig. 3 - INSIGHT case studies represented in a map of EU cities illustrated by population

By authors from EUROSTAT Geographical information

\begin{tabular}{|l|l|r|r|r|r|r|r|r|r|}
\hline \multirow{2}{*}{$\begin{array}{l}\text { VALIDATED } \\
\text { INDICATORS }\end{array}$} & \multirow{2}{*}{ Unit } & \multicolumn{2}{|c|}{ London } & \multicolumn{2}{c|}{ Madrid } & \multicolumn{2}{c|}{ Barcelona } & \multicolumn{2}{c|}{ Rotterdam } \\
\cline { 2 - 10 } & & $\begin{array}{c}\text { Central } \\
\text { City }\end{array}$ & $\begin{array}{c}\text { Metrop } \\
\text {. Area }\end{array}$ & $\begin{array}{r}\text { Central } \\
\text { City }\end{array}$ & $\begin{array}{c}\text { Metrop } \\
\text {.Area }\end{array}$ & $\begin{array}{c}\text { Central } \\
\text { City }\end{array}$ & $\begin{array}{c}\text { Metrop } \\
\text {. Area }\end{array}$ & $\begin{array}{c}\text { Central } \\
\text { City }\end{array}$ & $\begin{array}{c}\text { Metrop } \\
\text {. Area }\end{array}$ \\
\hline Population & $\begin{array}{l}\text { M. } \\
\text { Inhab. }\end{array}$ & 8.4 & $\mathbf{1 2 . 3}$ & 3.2 & $\mathbf{6 . 4}$ & 1.6 & $\mathbf{5 . 4}$ & 0.6 & $\mathbf{1 . 4}$ \\
\hline $\begin{array}{l}\text { Administrative } \\
\text { Area }\end{array}$ & $\mathrm{Km}^{2}$ & 1,595 & $\mathbf{1 2 , 0 9 1}$ & 606 & $\mathbf{7 , 9 6 1}$ & 98 & $\mathbf{7 , 7 1 6}$ & 208 & $\mathbf{1 , 2 4 3}$ \\
\hline $\begin{array}{l}\text { Population } \\
\text { density } \\
\text { (Theoretical) }\end{array}$ & $\begin{array}{l}\text { Inhab. } \\
/ \mathrm{km}^{2}\end{array}$ & 5,243 & $\mathbf{1 , 0 2 1}$ & 5,292 & $\mathbf{8 2 5}$ & 700 & $\mathbf{6 3 4}$ & 2,963 & $\mathbf{1 , 1 2 4}$ \\
\hline
\end{tabular}

Table 2 - General characteristics of INSIGHT case studies. Reference year: 2013

\section{METHODOLOGY AND RESULTS}

In this section we present the methodology used to determine the priority policy objectives in each city, followed by the results, which are summarized in tables. The set of indicators allow analysing the present state of the objectives on a comparative basis, by looking at their actual values (2013) in the four cities. Moreover, by looking at the annual growths of the 
indicators along the years, we can measure the evolution (2007-2013) of the objectives in each city. This paper considers these concepts and establishes the priorities having also into account the stakeholders' assessment. Finally, we analyse the role played by the land use and transport system in these policy objectives. The stages followed for this analysis have been:

- Set the theoretical framework, and support it by stakeholders' assessment (Table 1). This framework consists on a series of sustainability objectives to address the threats over cities, and indicators to measure them.

- Collection of the indicators from European and other international databases ${ }^{1}$, where the data for the four cities was available. The year of reference for the comparison among cities was the 2013. The period of reference for analysing the evolution in each city was 2007-2013 (Table 3)

- Comparison of the values of the indicators in the four cities for the year 2013 (Table 4). This comparison leads to analyse the most negative values considering their related objectives and some practical considerations (Table 4, indicators in red). The practical considerations are necessary since some indicators have resulted unappropriated for measuring their related objectives.

- Calculation of the annual growth rates of the indicators (Table 5). In order to prioritize the objectives, we need to measure the importance of the correspondent threat, and this means measuring evolution. This rates lead to analyse again the most negative values on a comparative basis, this time regarding evolution (Table 5, indicators in red)

- Qualitative analysis to establish the policy priorities (Table 6). This analysis considers the values of the indicators for the year 2013 as well as the evolution of the indicators during the period 2007-2013 and the policy makers' assessment.

- Policy priorities: the most important policy sustainability objectives in each city (Table 7). These priorities have been established on a comparative basis and have considered the magnitude of the trends threatening the cities. In this stage we analyse from a theoretical point of view the possible land use and transport strategies that could help to achieve the policy priorities.

\begin{tabular}{|c|c|c|c|}
\hline Sustainability objective & $\begin{array}{l}\text { No. validated } \\
\text { indicators }\end{array}$ & $\begin{array}{l}\text { No. indicators available for } \\
\text { the four cities } \\
\text { Reference year: } 2013\end{array}$ & $\begin{array}{l}\text { No. of indicators available for } \\
\text { analysing evolution in the } \\
\text { four cities } \\
\text { Reference period: } 2007-2013\end{array}$ \\
\hline Economic growth & 5 & 3 & 3 \\
\hline Economic efficiency & 3 & 3 & 2 \\
\hline $\begin{array}{l}\text { Liveable streets and } \\
\text { neighbourhoods }\end{array}$ & 5 & 3 & 3 \\
\hline $\begin{array}{l}\text { Equal, safe and secure } \\
\text { society }\end{array}$ & 11 & 3 & 1 \\
\hline $\begin{array}{l}\text { Stop demographic } \\
\text { decline }\end{array}$ & 4 & 1 & 1 \\
\hline $\begin{array}{l}\text { Reduce contribution to } \\
\text { climate change }\end{array}$ & 3 & 3 & 1 \\
\hline Reduce pollution & 6 & 2 & 2 \\
\hline Reduce urban sprawl & 3 & 3 & 1 \\
\hline
\end{tabular}

Table 3 - Collection of indicators for the year 2013 and for the hole period 2007-2013

1 OECD- Metropolitan Areas Aatabase, EUROSTAT- Regional Statistics, EUROSTAT- Urban Audit, EMTA Barometer, INRIX 


\begin{tabular}{|c|c|c|c|c|c|c|c|c|c|c|}
\hline \multirow{2}{*}{$\dot{0}$} & \multirow{2}{*}{$\begin{array}{l}\text { Indicators } \\
\text { (Sign) }\end{array}$} & \multirow{2}{*}{ Unit } & \multicolumn{2}{|c|}{ London } & \multicolumn{2}{|c|}{ Madrid } & \multicolumn{2}{|c|}{ Barcelona } & \multicolumn{2}{|c|}{ Rotterdam } \\
\hline & & & $\begin{array}{l}\text { Cent. } \\
\text { City }\end{array}$ & $\begin{array}{l}\text { Met.. } \\
\text { Area }\end{array}$ & $\begin{array}{l}\text { Cent. } \\
\text { City }\end{array}$ & $\begin{array}{l}\text { Met.. } \\
\text { Area }\end{array}$ & $\begin{array}{l}\text { Cent. } \\
\text { City }\end{array}$ & $\begin{array}{l}\text { Met.. } \\
\text { Area }\end{array}$ & $\begin{array}{l}\text { Cent. } \\
\text { City }\end{array}$ & $\begin{array}{l}\text { Met.. } \\
\text { Area }\end{array}$ \\
\hline \multirow{3}{*}{$\begin{array}{l}\text { F } \\
0 \\
0 \\
0 \\
.0 \\
0 \\
0 \\
0 \\
0 \\
0\end{array}$} & $\begin{array}{l}\text { GDP per capita } \\
(+)\end{array}$ & $\begin{array}{l}\text { / } \\
\text { inhab. }\end{array}$ & \multicolumn{2}{|r|}{55,598} & \multicolumn{2}{|r|}{31,004} & \multicolumn{2}{|r|}{29,671} & \multicolumn{2}{|r|}{36,500} \\
\hline & $\begin{array}{l}\text { Employment } \\
\text { rates of the } \\
\text { working } \\
\text { population }(+)\end{array}$ & $\%$ & \multicolumn{2}{|r|}{70.6} & \multicolumn{2}{|r|}{59.0} & \multicolumn{2}{|r|}{57.3} & \multicolumn{2}{|r|}{71.8} \\
\hline & Land price (+) & $€ / \mathrm{m}^{2}$ & $\begin{array}{r}10.70 \\
0\end{array}$ & 5.600 & & 2.200 & & 2.400 & & 1,600 \\
\hline \multirow{3}{*}{ 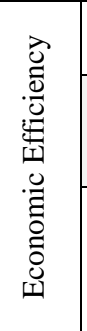 } & $\begin{array}{l}\text { Unoccupied } \\
\text { dwellings (-) }\end{array}$ & $\%$ & 2.0 & 2.3 & 11.6 & 9.3 & 12.9 & 10.2 & 9.3 & 6.1 \\
\hline & $\begin{array}{l}\text { Average time lost } \\
\text { in congestion per } \\
\text { driver (-) }\end{array}$ & $\begin{array}{l}\text { Hours/ } \\
\text { driver }\end{array}$ & & 101 & & 22 & & 28 & & 46 \\
\hline & $\begin{array}{l}\text { Labour } \\
\text { productivity } \\
\text { (added value per } \\
\text { worker) }(+) \\
\end{array}$ & $\begin{array}{l}€ / \\
\text { employ- } \\
\text { yed }\end{array}$ & & 78,366 & & 69,401 & & 67,048 & & 63,079 \\
\hline \multirow{3}{*}{ 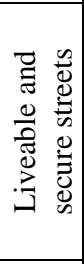 } & $\begin{array}{l}\text { Green space per } \\
\text { capita }(+)\end{array}$ & $\begin{array}{l}\mathrm{m}^{2} / \\
\text { inhab. }\end{array}$ & & 37.9 & & 27.4 & & 2.5 & & 72.4 \\
\hline & $\begin{array}{l}\text { No fatalities per } \\
10,000 \text { inhab. (-) }\end{array}$ & Ratio & & 0.183 & & 0.159 & & 0.317 & & 0.178 \\
\hline & $\begin{array}{l}\text { Exposure of the } \\
\text { population to air } \\
\text { pollutants (-) }\end{array}$ & $\mu \mathrm{g} / \mathrm{m}^{3}$ & & 10.3 & & 10.9 & & 11.1 & & 17.1 \\
\hline \multirow{7}{*}{ 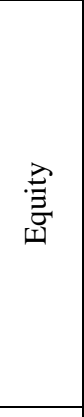 } & $\begin{array}{l}\text { PT supply : (+) } \\
\text { Bus }\end{array}$ & \multirow{5}{*}{$\begin{array}{l}\text { Veh-km } \\
\text { / inhab. }\end{array}$} & & 58.3 & & 41.4 & & 25.8 & & 13.3 \\
\hline & Metro & & & 9.0 & & 2.0 & & 4.0 & & 7.5 \\
\hline & Tram & & & 0.3 & & 4.9 & & 0.5 & & 5.6 \\
\hline & Train & & & - & & 5.4 & & 6.9 & & - \\
\hline & TOT & & & 67.6 & & 53.7 & & 37.2 & & 26.4 \\
\hline & $\begin{array}{l}\text { Income inequality } \\
\text { GINI index (-) }\end{array}$ & Ratio & & 0.555 & & 0.439 & & 0.462 & & 0.414 \\
\hline & $\begin{array}{l}\text { People at risk of } \\
\text { social exclusion(- } \\
\text { ) }\end{array}$ & $\%$ & \multicolumn{2}{|r|}{24.8} & \multicolumn{2}{|r|}{19.2} & \multicolumn{2}{|r|}{21.8} & \multicolumn{2}{|r|}{14.2} \\
\hline $\begin{array}{ll}\dot{00} & \Xi \\
\stackrel{\Xi}{\Xi} & : \\
\stackrel{\Xi}{0} & 0\end{array}$ & $\begin{array}{l}\text { Share of } \\
\text { population over } \\
65 \text { years(-) }\end{array}$ & $\%$ & 11.5 & 13.5 & 20.2 & 16.1 & 21.4 & 17.9 & 14.5 & 16.4 \\
\hline \multirow{3}{*}{ 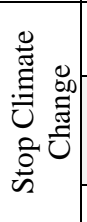 } & $\begin{array}{l}\text { GGE emissions } \\
\text { per capita }(-)\end{array}$ & $\begin{array}{l}\text { Tonnes/ } \\
\text { inhab. }\end{array}$ & & 7.9 & & 7.1 & & 5.7 & & 16.4 \\
\hline & $\begin{array}{l}\text { GGE emissions } \\
\text { by sector: } \\
\text { Transport } \\
\end{array}$ & \multirow[t]{2}{*}{$\%$} & & 31.2 & & 43.6 & & 39.4 & & 43.1 \\
\hline & Industry & & & 10.8 & & 1.9 & & 7.4 & & 11.4 \\
\hline \multirow[t]{2}{*}{ 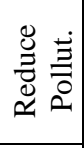 } & $\begin{array}{l}\text { Air pollutants } \\
\text { concentration(-): } \\
\mathrm{NO}_{2}\end{array}$ & \multirow[t]{2}{*}{$\mu \mathrm{g} / \mathrm{m}^{3}$} & & 36.7 & & 30.3 & & 31.8 & & 30.6 \\
\hline & $\mathrm{PM}_{10}$ & & & 18.5 & & 17.7 & & 21.6 & & 21.0 \\
\hline \multirow{3}{*}{ 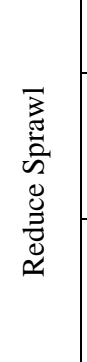 } & $\begin{array}{l}\text { Urbanised surface } \\
(-)\end{array}$ & $\mathrm{Km}^{2}$ & & 1,042 & & 1,043 & & 607 & & 440 \\
\hline & $\begin{array}{l}\text { Population } \\
\text { density } \\
\text { (in urbanised } \\
\text { surface) (-) }\end{array}$ & $\begin{array}{l}\text { Inhab/ } \\
\mathrm{km}^{2}\end{array}$ & & 8,077 & & 6,228 & & 8,305 & & 5,114 \\
\hline & $\begin{array}{l}\text { Share of the } \\
\text { metropolitan area } \\
\text { population living } \\
\text { in the city }\end{array}$ & $\%$ & & 60.3 & & 50.0 & & 29.6 & & 42.8 \\
\hline
\end{tabular}




\section{Table 4 - Values of the indicators associated to the objectives. Year 2013}

(Sign) (+) if a higher value of the indicator is positive for the achievement of the objective and (-) is the opposite Red colour: Indicators with the most negative values for their related objectives on a comparative basis Grey cells: Transport and land use indicators

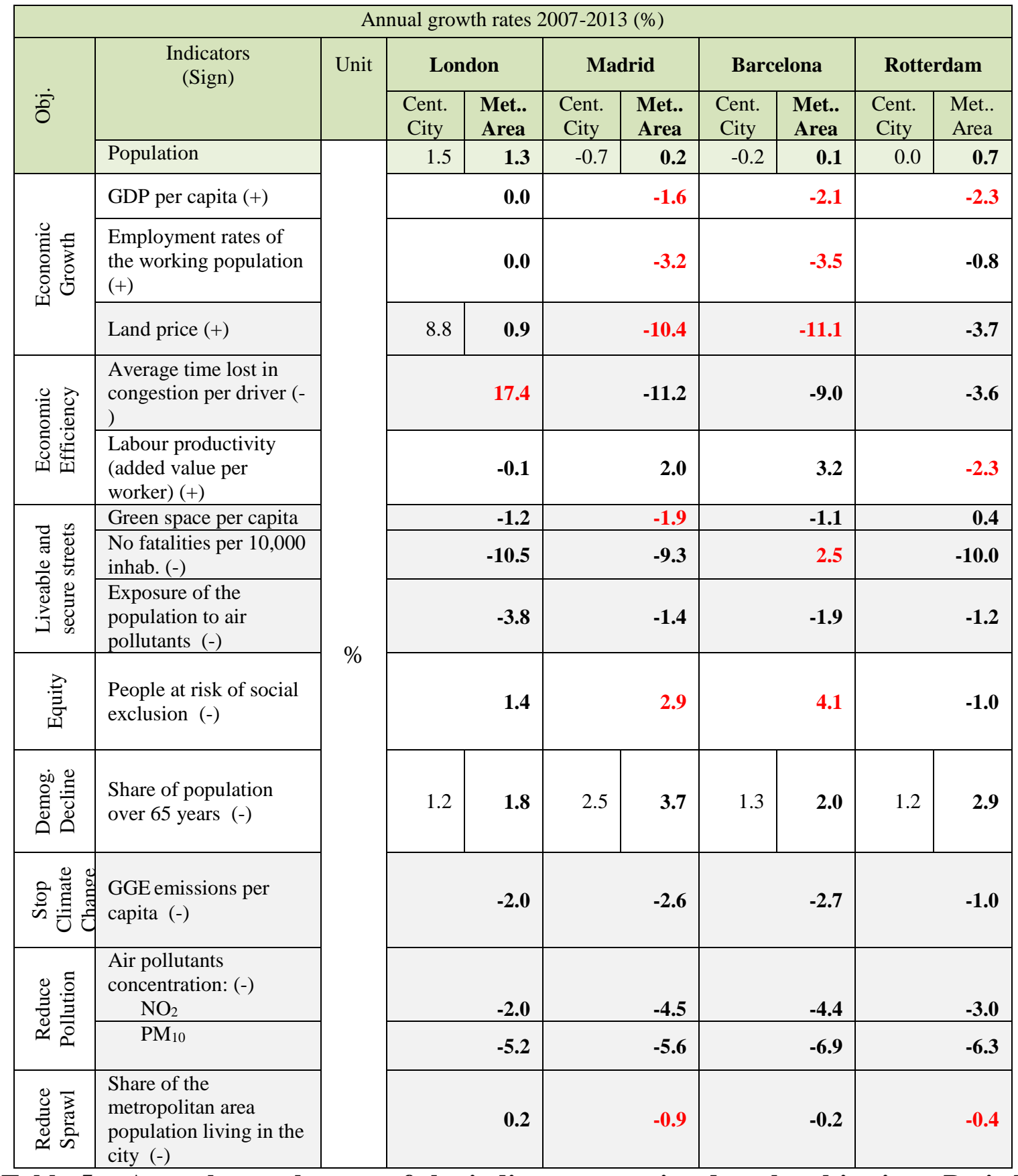

Table 5 - Annual growth rates of the indicators associated to the objectives. Period 2007-2013

Sign (+) if a growth in the value of the indicator is positive for the achievement of the objective and (-) is the opposite Red colour: Indicators whose evolution very negative for their related objectives on a comparative basis Grey cells: Transport and land use indicators 


\begin{tabular}{|c|c|c|c|c|}
\hline & London & Madrid & Barcelona & Rotterdam \\
\hline 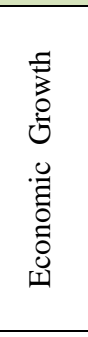 & $\begin{array}{l}\text { London presents the highest GDP per capita in } 2013 \text { and } \\
\text { especially the highest land prices. } \\
\text { Is the only city in this comparative that does not present a } \\
\text { negative evolution of economic indicators during the EU } \\
\text { economic recession (2007-2013). The land prices have even } \\
\text { grown in this period (this may indicate economic growth, but } \\
\text { it is probably negative for the objective of equity since affects } \\
\text { the costs of living). }\end{array}$ & \multicolumn{2}{|c|}{$\begin{array}{l}\text { Both Spanish cities present the lowest GDP per capita and employment rates. Moreover, all their } \\
\text { economic indicators have deteriorated significantly during the crisis period. The land prices have } \\
\text { dropped an average of } 10-11 \% \text { per year. Employment rates have declined by a } 3 \% \text { per year. } \\
\text { This negative evolution is of especial concern since it is related to other threats such as } \\
\text { demographic decline and social exclusion and polarisation. }\end{array}$} & $\begin{array}{l}\text { Rotterdam presents the highest } \\
\text { employment rate. The land prices are the } \\
\text { lowest in this comparative, but this is not } \\
\text { significant since the land prices decrease } \\
\text { with city sizes (Quigley, 1998). The } \\
\text { economic indicators present deterioration } \\
\text { during the generalised EU recession but } \\
\text { much less marked than in Madrid and } \\
\text { Barcelona. }\end{array}$ \\
\hline 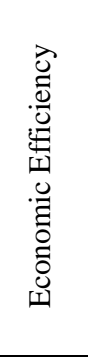 & $\begin{array}{l}\text { Only congestion seems to be a great and growing problem for } \\
\text { efficiency in London. However, congestion affects to the } \\
\text { energy use, noise, pollution and emissions. Therefore we are } \\
\text { going to consider the congestion reduction as priority for the } \\
\text { case of London. }\end{array}$ & \multicolumn{2}{|c|}{$\begin{array}{l}\text { Madrid and Barcelona behave very similarly in economic terms. Regarding economic efficiency } \\
\text { indicators: } \\
\text { - The rate of empty dwellings is high, especially in the central cities. This is an effect associated } \\
\text { to the gentrification (unaffordable prices in city centres) that make the population move to the } \\
\text { periphery) (Cameron, 2003), and is a reflection of the urban sprawl. } \\
\text { - The labour productivity has increased in the recession period (less workers but more } \\
\text { productive) } \\
\text { - The congestion levels are quite good compared to London and Rotterdam and the evolution is } \\
\text { positive. Probably associated to the slowdown of activities that leads to a reduction of transport } \\
\text { demand and traffic levels (Preston and Rajé, 2007) }\end{array}$} & $\begin{array}{l}\text { Rotterdam presents the highest labour } \\
\text { productivity loses in this comparative. } \\
\text { Unlike in the Spanish case studies, the } \\
\text { GDP of Rotterdam has fallen below the } \\
\text { employment rates, reducing the added } \\
\text { value created per worker. } \\
\text { Congestion in Rotterdam is high for the } \\
\text { size of the city. }\end{array}$ \\
\hline$\stackrel{\Xi}{.}$ & $\begin{array}{l}\text { The green space, exposure to pollution ad accident rates in } \\
\text { London present quite good values for being such a big city. In } \\
\text { addition, the evolution is in general positive. }\end{array}$ & $\begin{array}{l}\text { Madrid presents the lowest rate of fatalities per } \\
\text { capita in this comparative }\end{array}$ & $\begin{array}{l}\text { Barcelona presents the lowest green space } \\
\text { per capita and the highest number of } \\
\text { fatalities per capita. Moreover, these last } \\
\text { are growing. }\end{array}$ & $\begin{array}{l}\text { Rotterdam accounts for a lot of green space } \\
\text { per capita, although its population is highly } \\
\text { exposed to pollution. }\end{array}$ \\
\hline$\underset{\Xi}{\stackrel{\gtrsim}{\Xi}}$ & $\begin{array}{l}\text { The inequality index and the level of social exclusion are very } \\
\text { high in London compared to the rest of the cases. Therefore } \\
\text { we are going to consider Equity as a priority for this case. } \\
\text { Improving PT services helps to improve equity and inclusion } \\
\text { by improving accessibility. The PT supply of London results } \\
\text { to be the highest one, but this is not necessarily significant } \\
\text { since the indicator is too dependent on the city size (Alonso et } \\
\text { al., 2014) }\end{array}$ & $\begin{array}{l}\text { The percentage of people at risk of social exclusi } \\
\text { period 2007-2008, although more in Barcelona th } \\
\text { decline and job losses. }\end{array}$ & $\begin{array}{l}\text { grown in both Spanish cities in the } \\
\text { Madrid. This is related to the economic }\end{array}$ & $\begin{array}{l}\text { Unlike in the case of London, the equity } \\
\text { and social inclusion levels in Rotterdam are } \\
\text { the best in this comparative. The PT supply } \\
\text { is relatively small; this is not surprising, } \\
\text { since this indicator is very dependent on } \\
\text { the city size (Alonso et al., 2014). }\end{array}$ \\
\hline Еี๊ & \multicolumn{4}{|c|}{ 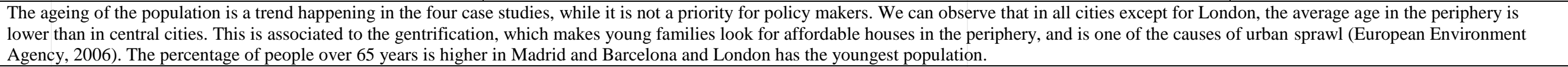 } \\
\hline 덩 六 & \multicolumn{4}{|c|}{ 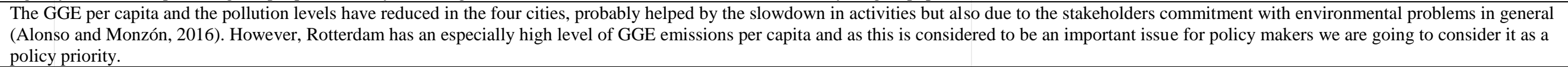 } \\
\hline
\end{tabular}


The urban sprawl in London does not seem to be a great concern compared to the other case studies. The land

occupation (urbanised surface) is not big for the size of the city, and the density is high. Moreover, it is the only city where the percentage of population living in the central city has not decreased.
Madrid has a widely dispersed urban population, and presents the biggest land occupation in this comparative. In addition, the population

movements to the metropolitan ring are very significant. During the period 2007-2013 the central city has been constantly loosing population weight. Therefore this is a priority concern in the city of Madrid.
Barcelona presents most dense urban population in this comparative. The percentage of people living in the central city is low, but this is due to the administrative organization of the city. However, this percentage has not

decreased as much as in Rotterdam or

Madrid.
Rotterdam accounts for the most dispersed urban population. Moreover, as has

occurred in Madrid, the central city has

been constantly loosing population weight over the whole metropolitan area.

Therefore this is a priority concern in the city of Rotterdam.

Table 6 - Qualitative analysis considering values from Tables 4 and 5 and the policy makers' assessment (Table 1) 


\begin{tabular}{|c|c|c|c|c|}
\hline & London & Madrid & Barcelona & Rotterdam \\
\hline 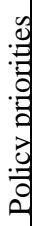 & $\begin{array}{l}\text { - Reduce congestion to } \\
\text { increase efficiency } \\
\text { - Equal society and avoid } \\
\text { social exclusion }\end{array}$ & $\begin{array}{l}\text { - Economic growth } \\
\text { - Reduce/ Stop urban } \\
\text { sprawl }\end{array}$ & $\begin{array}{l}\text { - Economic growth } \\
\text { - Increase liveability } \\
\text { equity and security }\end{array}$ & $\begin{array}{l}\text { - Reduce GGE } \\
\text { emissions, and pollution } \\
\text { exposure } \\
\text { - Reduce/ Stop urban } \\
\text { sprawl }\end{array}$ \\
\hline 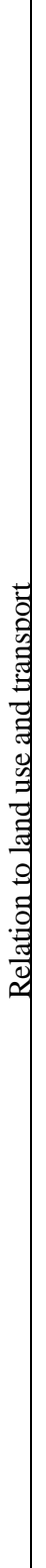 & $\begin{array}{l}\text { - The congestion is a } \\
\text { problem directly related } \\
\text { to the land use and } \\
\text { transport system, which } \\
\text { creates economic } \\
\text { inefficiencies and } \\
\text { environmental problems. } \\
\text { It is due to excessive car } \\
\text { use and it can be solved } \\
\text { by improving PT } \\
\text { services, enhancing soft } \\
\text { modes or pricing } \\
\text { measures (European } \\
\text { Commission, 2007) } \\
\text {-The social exclusion is } \\
\text { partially related to the } \\
\text { segregation of residential } \\
\text { zones according to } \\
\text { income, and exacerbates } \\
\text { social and economic } \\
\text { divisions, enhancing } \\
\text { inequality. The process } \\
\text { usually leads to a } \\
\text { growing degradation of } \\
\text { the poorest areas, whose } \\
\text { residents may be socially } \\
\text { excluded due to the lack } \\
\text { of accessibility to basic } \\
\text { needs, jobs or activities } \\
\text { (Preston and Raje, 2007). } \\
\text { Some urban planning } \\
\text { strategies can partly } \\
\text { address this problem. } \\
\text { Examples of these } \\
\text { strategies are the } \\
\text { promotion of tenure mix } \\
\text { in housing or the } \\
\text { improvement of } \\
\text { accessibility levels - by } \\
\text { improving PT or making } \\
\text { it more affordable to } \\
\text { access to these needs } \\
\text { (Coline et al., 2013). }\end{array}$ & $\begin{array}{l}\text { - Economic growth and } \\
\text { job creation depend on } \\
\text { demand, and cities can } \\
\text { stimulate demand in } \\
\text { many ways. In this } \\
\text { regard, land use and } \\
\text { transport management } \\
\text { could help in some way } \\
\text { to create a business- } \\
\text { friendly environment, by } \\
\text { providing good } \\
\text { accessibility, competent } \\
\text { transport networks or } \\
\text { even liveable } \\
\text { neighbourhoods } \\
\text { (Campbell et al., 2013). } \\
\text { These conditions can } \\
\text { attract both businesses } \\
\text { and people. } \\
\text { - Urban sprawl is clearly } \\
\text { a land use and transport } \\
\text { issue, defined as the } \\
\text { spread of low-density } \\
\text { settlements, and } \\
\text { considered as one of the } \\
\text { main challenges that } \\
\text { cities face (European } \\
\text { Union, 2011). This threat } \\
\text { can be addressed through } \\
\text { higher density } \\
\text { developments with good } \\
\text { public transport } \\
\text { connections, but also by } \\
\text { preventing migration to } \\
\text { peri-urban areas- } \\
\text { improving inner city } \\
\text { spaces in order to create } \\
\text { more liveable and } \\
\text { attractive environments } \\
\text { or promoting housing } \\
\text { mix to avoid } \\
\text { gentrification. }\end{array}$ & $\begin{array}{l}\text { - A liveable, equal and } \\
\text { secure city accounts for } \\
\text { good physical and social } \\
\text { environments (Sclappa } \\
\text { and Neil, 2013). } \\
\text { Therefore, land use and } \\
\text { transport strategies such } \\
\text { as the increase of green } \\
\text { areas and public spaces, } \\
\text { the improvement of } \\
\text { public services or the } \\
\text { reduction of space } \\
\text { dedicated to traffic and } \\
\text { the enlargement of areas } \\
\text { dedicated to pedestrians } \\
\text { and bicycles can help to } \\
\text { improve liveability, } \\
\text { equity and security }\end{array}$ & $\begin{array}{l}\text { - Urban areas consume } \\
\text { more than two thirds of } \\
\text { the total energy in EU, } \\
\text { mainly due to building } \\
\text { and transport sectors } \\
\text { (UN-HABITAT, 2009). } \\
\text { In addition, most of the } \\
\text { energy sources are not } \\
\text { renewable, and are } \\
\text { responsible for air } \\
\text { pollution and GGE. } \\
\text { Especially in the } \\
\text { transport sector where } \\
\text { the strong dependence on } \\
\text { cars and therefore on fuel } \\
\text { cause also air pollution } \\
\text { and noise (Enemark and } \\
\text { Kneeshaw, 2013). In the } \\
\text { case of Rotterdam a } 43 \% \\
\text { of GGE come from the } \\
\text { transport sector. } \\
\text { Urban strategies } \\
\text { designed to avoid sprawl, } \\
\text { would help to reduce the } \\
\text { environmental impact, } \\
\text { since the density of urban } \\
\text { areas allows for more } \\
\text { energy efficient forms of } \\
\text { housing, transport and } \\
\text { service provision } \\
\text { (European Union, 2011). } \\
\text { On response to car } \\
\text { dependence, policies } \\
\text { such as integrated land } \\
\text { use planning, } \\
\text { improvement of public } \\
\text { transport networks, car } \\
\text { restrictions or expansion } \\
\text { of infrastructures for } \\
\text { pedestrians and cyclists } \\
\text { are recommended } \\
\text { (European Commission, } \\
\text { 2007). }\end{array}$ \\
\hline
\end{tabular}

Table 7 - Policy priorities: the most important policy sustainability objectives in each city. Role of land use and transport strategies

\section{CONCLUSIONS}


European cities need to be sustainable, since they are the drivers of economic development and deliver many public services, such as education, healthcare and transportation (European Union, 2011). However, urban areas in Europe are facing some trends that have become real threats to their sustainable development. In this paper we present a set of policy objectives, which have been designed for the management of urban areas, in order to face the main threats existing over cities. The objectives have undergone a stakeholder's assessment: ten policy makers from European cities have evaluated them in terms of importance and have validated a series of indicators related to them. This framework has been used to evaluate the policy priorities of four European cities: London, Madrid, Barcelona and Rotterdam. By comparing the values of the indicators in each city for the year 2013 and measuring the evolution of the indicators during the period 2007-2013, we have determined the most important objectives for each city. The priority objectives will respond to the weakness or main threats of the cities: Madrid and Barcelona should especially address the threat of economic decline, Rotterdam the sprawl and London the social exclusion.

Finally, the role played by the land use and transport system in these policy objectives is analysed. This analysis is partially supported by the indicators used, half of which are related to the land use and transport system of the cities. Land use and transport strategies reducing congestion help to achieve economic efficiency, as well as policies enhancing PT and soft modes help to reduce exclusion, liveability or even sprawl.

\section{REFERENCES}

ALONSO, A., MONZON, A., CASCAJO, R., 2015. Comparative analysis of passenger transport sustainability in European cities. Ecological Indicators 48(0), 578-592

ALONSO, A., MONZON, A.., 2016. Assessing the progress towards sustainability and the role of urban transport- city of Madrid. 6th Transport Research Arena, April 18-21, 2016, Warsaw, Poland

CAMERON, S., 2003. Gentrification, housing redifferentiation and urban regeneration: 'Going for Growth in Newcastle upon Tyne. Urban Studies 40(12), 2367-2382.

CAMPBELLl, M., PARTRIDGE, A., SOTO, P., 2013. More jobs: better cities- a framework for a better action on jobs. Saint- Denis .URBACT

COLINI, L., CZISCHKE, D., GÜNTNER, S., TOSICS, I., \& RAMSDEN, P. ,2013. Against divided cities in Europe. Saint- Denis .URBACT 
DIRECTORATE- GENERAL FOR ECONOMIC AND FINANCIAL AFFAIRS OF THE EUROPEAN COMMISSION. 2009. Economic Crisis in Europe: Causes, Consequences and responses. Luxembourg. : Office for Official Publications of the European Communities.

ENEMARK, A., KNEESHAW, S. 2013. How cities can motivate mobility mindsets. SaintDenis .URBACT

EUROPEAN ENVIRONMENT AGENCY, 2006. Urban sprawl in Europe- The ignored challenge. Copenhagen.

EUROPEAN COMMISSION, 2007. Green Paper: Towards a new culture for urban mobility. COM (2007) 511 final. Brussels.

EUROPEAN COMMISSION, 2012. Green Paper- Restructuring and anticipation of change: what lessons from recent experience?. COM (2012) 7 final. Brussels: European Commission.

EUROPEAN UNION, 2011. Cities of Tomorrow- Challenges, visions, ways forward. Luxembourg.

GARCÍA, O., LUCIO, A., SALAS- OLMEDO, M.H., ROMANILLOS, G., ALONSO, A., FEIJOO, C., 2014. D2.1 Stakeholders consultation. INSIGHT 7FP - EC.

HAGHSHENAS, H., VAZIRI, M., 2012. Urban sustainable transportation indicators for global comparison. Ecological Indicators 15, 115-121.

NEWMAN, P., KENWORTHY, J., 1999. Sustainability and cities: overcoming automobile dependence. Island Press. Washington DC.

OECD, 2002. Policy instruments for achieving Environmentally Sustainable Transport. OECD Publishing, Paris.

PRESTON, J., RAJÉ, F., 2007. Accessibility, mobility and transport-related social exclusion. Journal of Transport Geography. 15(3), 151-160.

QUIGLEY, JOHN M.. 1998. "Urban Diversity and Economic Growth". The Journal of Economic Perspectives 12 (2). American Economic Association: 127-38 
ROMANILlOS, G., ALONSO, A., WANG, Y., 2014. D2.2 Urban planning and governance: current practices and new challenges. INSIGHT 7FP - EC

SCHLAPPA, H., NEILL, W. J., 2013. From crisis to choice: re-imagining the future in shrinking cities.URBACT

TANGUAY, G.A., RAJAONSON, J., LEFEBVRE, J., LANOIE, P., 2010. Measuring the sustainability of cities: An analysis of the use of local indicators. Ecological Indicators 10, 407-418.

UN-HABITAT, 2009. State of the world's cities 2008/2009. London

UNITED NATIONS, 1992. United Nations Conference on Environment \& Development Rio de Janerio, Brazil, 3 to 14 June 1992

\section{INSIGHT project webpage:}

http://www.insight-fp7.eu/

\section{Online databases consulted:}

EMTA Barometer

http://www.emta.com/spip.php?article267\&lang=en

\section{EUROSTAT}

Geographical information

http://ec.europa.eu/eurostat/cache/RSI/\#?vis=nuts2.labourmarket\&lang=en

General Statistics

http://ec.europa.eu/eurostat/web/population-demography-migration-projections/populationdata/database

Regional Statistics

http://ec.europa.eu/eurostat/web/regions/data/database

Urban Audit

http://ec.europa.eu/eurostat/web/cities/data/database

INRIX Traffic Score Card

http://inrix.com/scorecard/

OCDE- Metropolitan Areas Database

http://stats.oecd.org/Index.aspx?Datasetcode=CITIES 
CIT2016 - XII Congreso de Ingeniería del Transporte València, Universitat Politècnica de València, 2016. DOI: http://dx.doi.org/10.4995/CIT2016.2016.4091

This work is licensed under a Creative Commons Attribution-NonCommercial-NoDerivatives 4.0 International License (CC BY-NCND 4.0). 